\section{E-cigarettes and youth smoking: be alert but not alarmed}

\author{
Coral E Gartner
}

Conner et $a l^{1}$ and Best et $a l^{2}$ report the results of two longitudinal studies of teenagers in the UK that examined the relationship between vaping an e-cigarette and smoking a cigarette. Similar to studies conducted in the USA, ${ }^{34}$ they both report an association between experimentation with vaping and subsequent experimentation with smoking. Fears that an increase in vaping will lead to an increase in smoking among young people via a 'gateway' effect have been used to support greater regulation of vaping products ${ }^{5}$ or to advocate for continued prohibition of vaping products containing nicotine in countries that do not allow their sale, possession or use by adults. ${ }^{6}$ Are these reasonable responses to these research findings?

Several things should be considered in the interpretation of these studies.

1. A proportion of the young people who try vaping and then smoking would have also tried smoking without trying vaping due to a common liability to experiment with substance use. ${ }^{57}$

2. It is plausible that vaping may increase the likelihood of experimenting with smoking through increased familiarity with a behaviour that resembles smoking and/or curiosity about how the two experiences compare. ${ }^{78}$ But it is unknown how many of those who might try smoking who would not have done so without trying vaping first will then go on to become regular smokers.

3. The baseline waves of these longitudinal studies were conducted in locations and at times when there were no age restrictions on sales of vaping products. ${ }^{2}$ In such a regulatory context, it is not surprising that young people may have tried the product with less restrictions first. ${ }^{5}$ This pattern may change as $18+$ age restrictions are adopted in more jurisdictions.

The Faculty of Medicine, School of Public Health, University of Queensland, Herston, Queensland, Australia

Correspondence to Dr Coral E Gartner, School of Public Health, University of Queensland, The Public Health Building, Corner of Wyndham St and Herston Road, Herston, QLD 4006, Australia;

c.gartner@uq.edu.au
4. The absolute number of young people regularly vaping or smoking remains low and appears to be decreasing. ${ }^{9}$

There is a growing evidence base that e-cigarettes are assisting smoking cessation among adult smokers at the population level. Using cross-sectional data from adults in the UK who had smoked in the past year, Brown et al found that smokers who used an e-cigarette had $60 \%$ greater odds of successfully quitting compared with those who used standard nicotine replacement therapy or no cessation aid. ${ }^{10}$ Zhu et al found that adult smokers in the 2014-2015 US Current Population Survey-Tobacco Use Supplement who used e-cigarettes were more likely to have successfully quit smoking for at least 3 months compared with non-users. Furthermore, the authors noted that for the first time since 2001, overall quit rates had increased, suggesting that vaping has led to an increase in quitting at the population level. ${ }^{11}$ Analysing US data from the 2014 and 2015 National Health Interview Surveys, Giovenco and Delnevo found that among adults who had smoked in the past 5 years, daily vaping was the factor most strongly associated with smoking cessation. ${ }^{12}$ Longitudinal data reported by Zhang et al found that longterm vaping (at least 2 years) was associated with a fourfold higher odds of quitting than among non-users, adjusted for baseline characteristics of the sample. ${ }^{13}$ Biener and Hargreaves also observed that daily vaping for at least a month was associated with sixfold greater odds of quitting smoking in another longitudinal study. ${ }^{14}$ Similarly, Hitchman et al observed daily vaping with advanced devices (tank systems) in the UK to be associated with quit success. ${ }^{15}$ Studies of youth experimentation with vaping and smoking should be considered in tandem with these findings that suggest a benefit for adult smokers. Increasing quitting among adult smokers is vital to reducing smoking prevalence and will result in much faster declines than relying only on reducing youth uptake. ${ }^{16}$

What is the most appropriate policy response to these studies that show an association between youth experimentation with vaping and experimentation with smoking? The authors of most of these studies have suggested their findings support ongoing monitoring and/or restricting youth access to vaping products. ${ }^{1-4}$ Some research has suggested that banning sales to minors could have the perverse effect of increasing youth smoking. ${ }^{17}$ Evidence from Sweden also suggests youth uptake of snus helped reduce smoking among young men. ${ }^{18}$ Nonetheless, facilitating youth uptake of vaping as a harm reduction strategy is unlikely to sit comfortably with many in the public health community, policy makers, parents and the general public. Surveys of vapers show widespread support for allowing sales only to adults, ${ }^{19-21}$ and this policy is also supported by vaping trade associations. ${ }^{22}$ As teens who are regular smokers could benefit from switching to vaping, it may be justifiable to allow some restricted access, such as via parental supply, medical prescription and/or smoking cessation clinics. However, limiting retail sales of vaping products to adults appears to be well supported and uncontroversial.

Reassuringly, current evidence has not shown an increase in youth smoking since the increase in vaping in the USA or UK. Indeed, the very low level of regular smoking and vaping seen in these longitudinal studies is one of the reasons they have used 'ever use' (even one puff) or any use in the past month to measure vaping and smoking. Between 2011 and 2016, any smoking in the past 30 days declined from $6.3 \%$ to $4.3 \%$ among middle school students and from $21.8 \%$ to $13.8 \%$ among high school students in the USA. ${ }^{23}$ The very low prevalence of smoking among young people is good news that should be celebrated; however, we should remain alert and continue to closely monitor youth vaping and smoking behaviours.

We should not be alarmed about these research findings because overreaction could lead to unintended consequences. Excessive regulation that prevents or deters smokers from switching from smoking to vaping could have the perverse outcome of retaining the most harmful nicotine product (the combustible cigarette) as the most widely used. The best protection against youth smoking uptake would come from radically transforming the current nicotine market so that tobacco cigarettes are no longer sold as an ordinary consumer item alongside bread and milk.

The advent of vaping products that are viable substitutes for combustible cigarettes could well provide the leverage needed to achieve this. ${ }^{24} \mathrm{~A}$ number of endgame strategies to end the cigarette epidemic have been proposed ${ }^{25}$ and increasingly a role for reduced harm nicotine products, such as e-cigarettes, is being recognised in such proposals. ${ }^{26} 27$ 
In determining how we respond to research on youth vaping and smoking, we need to consider the whole population (youth and adults) and longer term goals, such as a cigarette endgame. The goal of policy making should be to achieve the optimal regulatory balance that reduces any potential risks that vaping products may pose to young non-smokers while maximising the potential benefit that access to these products could provide to current smokers. ${ }^{28}$ In the meantime, ongoing monitoring of smoking and vaping and the relationship between these two behaviours among youth and adults is needed to better understand the potential risks and benefits of vaping products.

Correction notice This article has been corrected since it published Online First. To improve the wording, we have replaced "widespread support for restricting sales to adults" with "widespread support for allowing sales only to adults" in the article.

Contributors This manuscript was solely written by CEG.

\section{Competing interests None declared.}

Provenance and peer review Commissioned; internally peer reviewed.

(C) Article author(s) (or their employer(s) unless otherwise stated in the text of the article) 2018. All rights reserved. No commercial use is permitted unless otherwise expressly granted.

\section{Check for updates}

To cite Gartner CE. Tob Control 2018;27:359-360. Published Online First 8 September 2017

\section{CLlinked}

- http://dx.doi.org/10.1136/tobaccocontrol-2016053539

- http://dx.doi.org/10.1136/tobaccocontrol-2017053691

Tob Control 2018:27:359-360.

doi:10.1136/tobaccocontrol-2017-054002

\section{REFERENCES}

1 Conner M, Grogan S, Simms-Ellis R, et al. Do electronic cigarettes increase cigarette smoking in UK adolescents? Evidence from a 12-month prospective study. Tob Control 2018;27:365-72.

2 Best C, Haseen F, Currie D, et al. Relationship between trying an electronic cigarette and subsequent cigarette experimentation in Scottish adolescents: a cohort study. Tob Control 2018;27:373-8.

3 Miech R, Patrick ME, O'Malley PM, et al. E-cigarette use as a predictor of cigarette smoking: results from a 1-year follow-up of a national sample of 12th grade students. Tob Control 2017;26:e106-e111.

4 Wills TA, Knight R, Sargent JD, et al. Longitudinal study of e-cigarette use and onset of cigarette smoking among high school students in Hawaii. Tob Control 2017:26:34-9.

5 Etter JF. Gateway effects and electronic cigarettes. Addiction 2017 (Epub ahead of print: 7 Aug 2017).

6 Chapman S, Daube M, Bareham D, et al. Submission to the standing committee on health, aged care and sport on electronic cigarettes and vapourisers: submission 313. Inquiry into the use and marketing of electronic cigarettes and personal vaporisers in Australia. Canberra: Parliament of Australia, 2017. http://www.aph.gov.au/ DocumentStore.ashx?id=7f8c1204-79ed-402f-ae4420b4d1e8191d\&subld=512672. (accessed 20 Aug 2017).

7 Kozlowski LT, Warner KE. Adolescents and e-cigarettes: objects of concern may appear larger than they are. Drug Alcohol Depend 2017;174:209-14.

8 Schneider S, Diehl K. Vaping as a catalyst for smoking? An initial model on the initiation of electronic cigarette use and the transition to tobacco smoking among adolescents. Nicotine Tob Res 2016;18:647-53.

9 Jamal A, Gentzke A, Hu SS, et al. Tobacco use among middle and high school students_-United States, 2011-2016. MMWR Morb Mortal Wkly Rep 2017:66:597-603.

10 Brown J, Beard E, Kotz D, et al. Real-world effectiveness of e-cigarettes when used to aid smoking cessation: a cross-sectional population study. Addiction 2014;109:1531-40.

11 Zhu SH, Zhuang YL, Wong S, et al. E-cigarette use and associated changes in population smoking cessation: evidence from US current population surveys. $B M J$ 2017:358:i3262.

12 Giovenco DP, Delnevo CD. Prevalence of population smoking cessation by electronic cigarette use status in a national sample of recent smokers. Addict Behav 2018;76:129-34.

13 Zhuang YL, Cummins SE, Y Sun J, et al. Long-term e-cigarette use and smoking cessation: a longitudinal study with US population. Tob Control 2016;25(Suppl 1):i90-5.
14 Biener L, Hargraves JL. A longitudinal study of electronic cigarette use among a population-based sample of adult smokers: association with smoking cessation and motivation to quit. Nicotine Tob Res 2015; 17:127-33.

15 Hitchman SC, Brose LS, Brown J, et al. Associations between e-cigarette type, frequency of use, and quitting smoking: findings from a longitudinal online panel survey in Great Britain. Nicotine Tob Res 2015;17:1187-94.

16 Gartner CE, Barendregt JJ, Hall WD. Predicting the future prevalence of cigarette smoking in Australia: how low can we go and by when? Tob Control 2009;18:183-9.

17 Friedman AS. How does electronic cigarette access affect adolescent smoking? I Health Econ 2015:44:300-8.

18 Gartner C. Commentary on Pedersen \& von Soest (2014): increasing snus use among Norwegian adolescents - evidence of harm reduction effects? Addiction 2014;109:1163-4.

19 Fraser D, Weier M, Keane H, et al. Vapers' perspectives on electronic cigarette regulation in Australia. Int $J$ Drug Policy 2015;26:589-94.

20 Farrimond $\mathrm{H}$. E-cigarette regulation and policy: UK vapers' perspectives. Addiction 2016;111:1077-83.

21 Wackowski OA, Delnevo CD. Smokers' attitudes and support for e-cigarette policies and regulation in the USA. Tob Control 2015;24:543-6.

22 Independent British Vape Trade Association. Code of conduct/terms and conditions. Secondary code of conduct/terms and conditions, 2016. http://www.ibvta org.uk/join-us/code-of-conduct

23 Centers for Disease Control and Prevention (CDC). Current tobacco use among middle and high school students-United States, 2011. MMWR Morb Mortal Wkly Rep 2012:61:581-5.

24 Hefler M. The changing nicotine product landscape: time to outlaw sales of combustible tobacco products? Tob Control 2017.

25 McDaniel PA, Smith EA, Malone RE. The tobacco endgame: a qualitative review and synthesis. Tob Control 2016;25:594-604.

26 Gottlieb S, Zeller M. A nicotine-focused framework for public health. N Engl J Med 2017 (Epub ahead of print: 16 Aug 2017).

27 Thornley L, Edwards R, Waa A, et al. Achieving smokefree Aotearoa by 2025. Wellington, Aotearoa New Zealand: The Quit Group Trust, 2017. https:// aspire2025.org.nz/hot-topics/smokefree-action-plan/ (accessed 18 Aug 2017).

28 Beaglehole R, Bonita R, Yach D, et al. A tobacco-free world: a call to action to phase out the sale of tobacco products by 2040. Lancet 2015;385:1011-8. 


\section{Correction: E-cigarettes and youth smoking: be alert but not alarmed}

Gartner CE. E-cigarettes and youth smoking: be alert but not alarmed. Tob Control 2017;27:359-60. doi: 10.1136/tobaccocontrol-2017-054002.

The author of this editorial published in the 27(4) issue has requested that reference 6 "Chapman S, Daube M, Bareham D, et al. Submission to the standing committee on health, aged care and sport on electronic cigarettes and vapourisers: submission 313. Inquiry into the use and marketing of electronic cigarettes and personal vaporisers in Australia. Canberra: Parliament of Australia, 2017. http://www.aph.gov.au/DocumentStore.ashx?id=7f8c120479ed-402f-ae44-20b4d1e8191d\&subId=512672. (accessed 20 Aug 2017)." be replaced with the following reference, which more directly supports the text.

6. Ministry of Health Singapore. FAQs on E-Cigarettes, Vaporisers and Heat-Not-Burn Tobacco Products. 26 Jan 2018 https://www.moh.gov.sg/content/moh_web/home/pressRoom/ Current_Issues/2018/faqs-on-e-cigarettes--vaporisers-and-heat-not-burn-tobacco-produ.html (accessed 21 Jul 2018).

(C) Author(s) (or their employer(s)) 2018. No commercial re-use. See rights and permissions. Published by BMJ.

Tob Control 2018;27:599. doi:10.1136/tobaccocontrol-2017-054002corr1

D) Check for updates 